\title{
兵庫県南部地震の際の船舶乗組員及び漁業関係者の 異常体験に関するアンケート調查
}

\author{
石田＼cjkstart廣史*・千頭

\section{Questionnaire on Abnormal Experience of Seamen and Fishermen at the Southern Hyogo Great Earthquake}

亨*

\author{
Hiroshi ISHIDA and Toru CHIKAMI
}

\begin{abstract}
On the 17th of January, 1995, the Southern Hyogo Great Earthquake hitted the Hanshin District and damaged it seriously. At the earthquake, many ships were sailing, anchoring, fishing and so on, and many seamen and fishermen had experienced quite abnormal shocks and/or phenomena on board.

The questionnaire research was made on abnormal experiences and phenomena they had on board and their actions at that time. It showed that many of them felt severe vertical shocks as their ships stroke aground and/or serious engine troubles like explosion. And in many ships, many actions were taken to recognize and manage their safety against such emergency, and those worked relatively well eventhough some ships did not get suitable actions. On the other hand, many ships faced serious difficulty getting contact with the competent authorities concerned and had earth quake information from TV. Fishery situations were also seriously changed.
\end{abstract}

\section{1.はじめに}

1995年 1 月17日05時46分、兵庫県淡路島北端の明石海峡中央部を震源とするM7.2の兵庫県南部地震が淡 路島及び阪神地域一帯を襲い、約 6 千名もの数多くの尊い人命と約 10 兆円にも及莫大な社会・個人資産

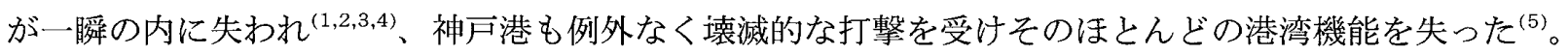

一方、その際に大阪湾を初めとする周辺海域を航行、停泊、操業中の船舶乗組員や漁業関係者は、今ま でに経験したことのないような様々な激しい異常を体験し、そして多くの船舶は自船の安全確認や航行の ため、当時の状況に対応した各種様々な行動を取った。これらに関する一部のアンケート調查や記録は既 に報告 ${ }^{(6,7)}$ れているが、より広範囲な調查を行い今後の教育・研究の資料の一つとして、地震発生時にお ける海上における様々な状況や船舶の行動に関する記録を保存し又、船舶の安全及び危機管理の実態や問 題点を明らかにする必要がある。そこで、大阪湾周辺海域を主な航行、操業海域とする船舶ならびに漁業 関係者に対して、兵庫県南部地震の際の異常体験についてアンケート調查を実施した ${ }^{(8)}$ 。

本報では、これらのアンケート調査に基づいた中間報告 ${ }^{(9)} に$ 続いて、船舶及び漁業関係者の地震発生時の 海震の感じ方や、感じた異常に対する行動、安全及び危機管理の対策そして情報入手など又、漁況変化の 影響などについて報告する。

\section{2.アンケート調査概要}

本アンケート調查は1994年夏以降に、大阪府下および兵庫県下の27漁業協同組合、17フェリー旅客船運

*正会員＼cjkstart神戸商船大学（T658＼cjkstart神戸市東灘区深江南町5-1-1） 
航会社、9 内航海運会社、 官庁 · 水先人協会の 4 団体、 大阪・神戸港の 11 曳船会社 に対して実施し、そしてそ れらから合計227回答を回収 した。さらに漁業協同組合 に対しては漁況・海象調査 のため訪問調查も実施した。

回答者の年令構成は 30 、

40、50歳代がそれぞれ39、

43、65回答と最も多く、20 と60歳代がそれぞれ18と16 回答を占めた。70歳以上も 1 回答あった。回答者の職 種は職務上の性質から船長、 航海士がそれぞれ62、30回 答と多く、次いで機関長 13 、 機関士 3 であった。単に乗 組員とした回答が 41 もっ た。

アンケート調查の回答か

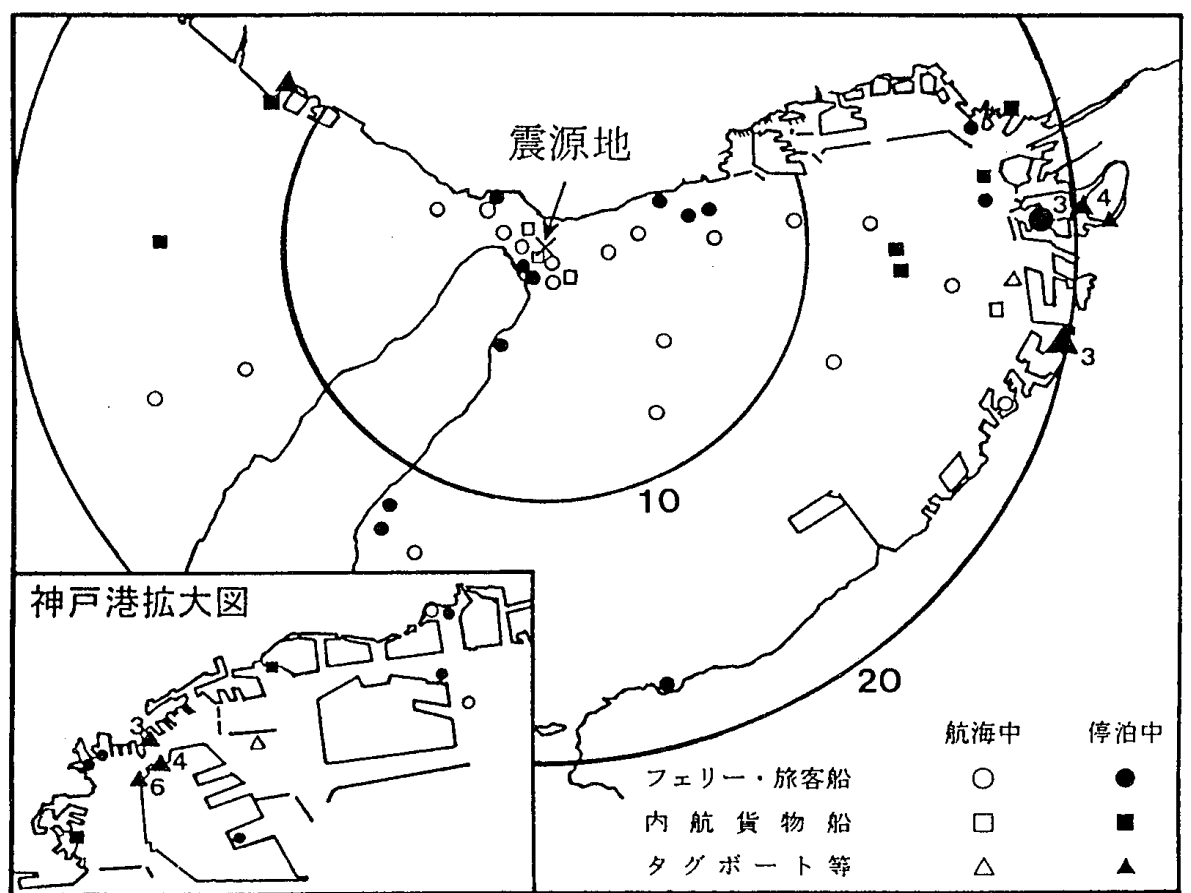

図 1 地震発生時の船舶の位置と航行状況

図中の船位及び航行状況はアンタート調查で船位が明らかであった77隻について表示。 図中の各種マーク付近の数字は複数船舶の隻数を示す。

ら合計106隻の船舶が確認された。これらの船舶の地震発生時の位置を震源地から距離分布で見ると、20マ イルまでの各 5 マイル毎には17〜26隻分布し、20マイル以遠にも7隻分布していた。又、航行中は36隻、 錨泊中 10 隻、係船中 48 隻、操業中 8 隻、不明 4 隻となっていた。図 1 にこれらの内、位置不明船と漁船（操 業中のため移動、凡その海域しか判明しない）を除いた合計77隻（7隻は図外に位置する）の船位、船種 及び状態を示す。図から判るように、地震発生当時かなりの船舶が大阪湾周辺海域で航行、停泊しており、 海震に伴う激しい異常を多くの船舶及び漁業関係者が経験したことが判る。なお、本アンケート調査の実 施や基本解析結果については既に詳細な報告( $(8,9,10)$ がなされている。

\section{3.アンケート調査解析結果}

\section{1 海震の感じ方及び地震後の船舶の行動分類} アンケート回答中には、海震の感じ方及び地震 後に船舶が取った行動には種々の表現が見られた。 それぞれの表現を表 1 のよりまとめて分類し、 以後の解析上の分類として用いる。表 1 に示すよ うに、感じ方の分類では多くのアンケート回答が 乗揚げたような強い衝撃、縱摇れ、上下動等の表 現を用いた。これらを「垂直衝撃」とし、同様に

「水平衝撃」、異常音」そして「機関異常」と分 類した。地震発生後、船舶はそれぞれの状況に対 応するため、自船の安全確認や航行のため各種の 安全対策や行動を取った。これら船舶が取った対 策や行動を、船体や機関点検を初めとする種々の 点検行動を「点検」、機関の減速や停止等の「機関 操作」、航行や操業の「予定变更」そして運航管 理者や関係所轄官庁との「通報連絡」とに分類さ
表 1 海震の感じ方と地震後の船舶の行動分類

\begin{tabular}{|c|c|}
\hline 分 類 & アンケート回答中の表現例 \\
\hline \multicolumn{2}{|l|}{ （感じ力） } \\
\hline 垂直德擊 & $\begin{array}{l}\text { 乗揚げた 突き上げた } \\
\text { 上下持ち上がった }\end{array}$ \\
\hline \multirow{3}{*}{$\begin{array}{l}\text { 水平衝撃 } \\
\text { 異 常 音 } \\
\text { 機関異常 }\end{array}$} & 衝突した 接触した 水平動 横㬳れ \\
\hline & ドーンという音＼cjkstart鿉擊音＼cjkstart振動音＼cjkstart辢 \\
\hline & 主機の爆発＼cjkstart主機の突然発動＼cjkstart機関に異常 \\
\hline & 回転数異常 プロペラが空転 CPPの買破損 \\
\hline & クラッシュアスターン \\
\hline \multicolumn{2}{|l|}{ （行 動） } \\
\hline \multirow[t]{2}{*}{ 点検 } & $\begin{array}{l}\text { 船体点検 機関点検 操拕機点検 船内点検 } \\
\text { 荷役保留設備点検 船位確認 周囲海域確認 }\end{array}$ \\
\hline & 旅客安全確㒛 ビルジ検測 サウンディング \\
\hline 機甬定変更 & 目的地変更 引き返す 緊急出港 港外避難 \\
\hline & 機関S/B 運航中止 帰港 \\
\hline \multirow[t]{2}{*}{ 通報連絡 } & 打合せ（代理店 運航管理者） 僚船䦎連絡 \\
\hline & 海上保安仃＼cjkstart津波情報＼cjkstart岸壁状況 \\
\hline
\end{tabular}


れる。

\section{2 海震の感じ方と地震後の船舶の行 動}

震源地からの距離別の海震の感じ方と、 地震後の安全対策及び航行のために船舶 が取った行動分類を表 2 に示す。震源地 から 5 マイル以内の船舶の約 8 割は「垂 直衝撃」を感じたが、「水平衝撃」などの 比率は低い。震源地汃ら20マイル以内の 船船は 4 割〜 8 割の高い比率で「垂直衝 撃」を感じ、他の感じ方の比率より高い。 10〜15マイルの船舶は高い比率で「機関 異常」感じたが、他の感じ方の比率はあ まり高くない。

地震後、船舶が自船の安全確認や航行 のために取った安全対策や行動は、5マ イル以内の船船では約 9 割が「点検」、約 7 割が「機関操作」 10 15マイルの船舶 では約 7 割が「点検」と、高い比率で「点 検」と「機関操作」の行動を取った。自 船の安全確認のため当然のことではある が、「点検」が震源地からの距離にあまり 関係なく高い比率を示し、全体でも 5 割 あった。「機関操作」及び「予定変更」は 全体で約 3 割で通報連絡は約 1 割であっ た。このことは地震当時、安全確認及び 対策を取ることを先ず第一としたことが らかが党る。「通報連絡」の比率が低かっ たのは、地震による陸上の通信網の被害 が甚大でほとんど通信不能となり、陸上 と海上との連絡が取れなかったことにも 一部起因すると考えられる。

総トン数別の海震の感じ方と地震発生 後の船舶の安全確認や航行のために取っ た行動分類を表 3 に示す。総トン数 2 千 トン以上の船舶は約 8 割と高い比率で「垂 直衝撃」を感じ、そして 7〜8 割の高い 比率で「点検」を実施している。大きな 船舶の方が「垂直衝撃」をより強く感じ、 船体及び機関の点検を実施したことが判 る。しかし一方、 $2 \sim 3$ 割もの大型船舶 が「点検」も実施せず他の行動を取った こと又、小型船舶のその比率は $2 \sim 3$ 割 と低いのは、異常時の緊急・安全管理上 対策に問題が残る。

3.3 海震の感じ方別の船舶の行動

海震の感じ方の内、比率の高かった「垂
表 2 震源地からの距離別の海震の感じ方と地震後の船舶の行動

\begin{tabular}{|c|c|c|c|c|c|c|c|c|c|}
\hline \multirow{2}{*}{$\begin{array}{l}\text { 距離 } \\
\text { (マ倠) }\end{array}$} & \multirow{2}{*}{ 隻数 } & \multicolumn{4}{|c|}{ 海震の感じ方（\%） } & \multicolumn{4}{|c|}{ 艧舶の行動（\%） } \\
\hline & & $\begin{array}{l}\text { 垂直 } \\
\text { 衝䡈 }\end{array}$ & $\begin{array}{l}\text { 水平 } \\
\text { 衙擊 }\end{array}$ & $\begin{array}{l}\text { 巽常 } \\
\text { 音 }\end{array}$ & $\begin{array}{l}\text { 機関 } \\
\text { 異常 }\end{array}$ & 点㭘 & $\begin{array}{l}\text { 機関 } \\
\text { 操作 }\end{array}$ & $\begin{array}{c}\text { 予定 } \\
\text { 変更 }\end{array}$ & $\begin{array}{l}\text { 通報 } \\
\text { 連䊀 }\end{array}$ \\
\hline $0-5$ & 17 & 76 & 24 & 12 & 29 & 88 & 65 & 24 & 18 \\
\hline $5-10$ & 22 & 36 & 23 & 9 & 18 & 41 & 14 & 45 & 23 \\
\hline $10-15$ & 19 & 58 & 16 & 26 & 63 & 74 & 37 & 42 & 16 \\
\hline $15-20$ & 26 & 50 & 12 & 15 & 35 & 42 & 23 & 31 & 12 \\
\hline 20 以上 & 13 & 31 & 23 & 15 & 38 & 46 & - & 31 & 8 \\
\hline 不明 & 9 & 11 & - & 11 & - & 11 & - & - & - \\
\hline 合計 & 106 & 47 & 17 & 15 & 33 & 53 & 25 & 32 & 14 \\
\hline
\end{tabular}

各距離別および合計の感じ方や行動相の数字は、それそれ各距離別船舶隻 数および合計船船隻数に対する比率（\%）を示す。回答は複数回答を含む。

表 3 総トン別の海震の感じ方と地震後の船舶の行動

\begin{tabular}{|c|c|c|c|c|c|c|c|c|c|}
\hline \multirow{2}{*}{ 総トン数 } & \multirow{2}{*}{ 隻数 } & \multicolumn{4}{|c|}{ 海震の感じ方（\%） } & \multicolumn{4}{|c|}{ 船舶の行動（\%） } \\
\hline & & $\begin{array}{l}\text { 垂直 } \\
\text { 䍋撃 }\end{array}$ & $\begin{array}{l}\text { 水平 } \\
\text { 衝敦 }\end{array}$ & $\begin{array}{l}\text { 異常 } \\
\text { 咅 }\end{array}$ & $\begin{array}{l}\text { 機関 } \\
\text { 異常 }\end{array}$ & 点検 & $\begin{array}{l}\text { 機関 } \\
\text { 操作 }\end{array}$ & $\begin{array}{l}\text { 予定 } \\
\text { 変更 }\end{array}$ & $\begin{array}{l}\text { 通啈 } \\
\text { 連絡 }\end{array}$ \\
\hline $0-20$ & 19 & 21 & - & - & 42 & 21 & 26 & 42 & - \\
\hline 20-2百 & 29 & 28 & 17 & 17 & 21 & 31 & 7 & 28 & - \\
\hline 2百 -2 千 & 25 & 48 & 16 & 24 & 20 & 72 & 24 & 28 & 24 \\
\hline 2千-5千 & 13 & 77 & 31 & 8 & 46 & 77 & 46 & 54 & 31 \\
\hline $5 \mp-1 万$ & 13 & 85 & 23 & 15 & 62 & 77 & 38 & 23 & 31 \\
\hline 1万以上 & 7 & 71 & 29 & 29 & 29 & 71 & 43 & 14 & 14 \\
\hline 合計 & 106 & 47 & 17 & 15 & 33 & 53 & 25 & 32 & 14 \\
\hline
\end{tabular}

各紷トン数別および合計の感じ方や行動欄の数字は、それぞれ各トン数別船 船隻数および合計船舶隻数に対する比率（\%）を示す。回答は複数回答を含

表 4 総トン数別の垂直衝撃と機関異常を感じた船舶の行動

\begin{tabular}{|c|c|c|c|c|c|c|c|c|c|c|}
\hline \multirow{3}{*}{ 総トン数 } & & & \multicolumn{4}{|c|}{ 船 舶 } & \multicolumn{4}{|c|}{ 動（\%） } \\
\hline & \multicolumn{2}{|c|}{ 雙数 } & \multirow{2}{*}{ 点 } & 娭 & \multicolumn{2}{|c|}{ 機関操作 } & \multicolumn{2}{|c|}{ 予定変更 } & \multicolumn{2}{|c|}{ 通報連䅂 } \\
\hline & 䡩 & 灀 & & 略 & 䡩 & 縕 & 重直 & 眮 & 堹直 & 㽢 \\
\hline $0-20$ & 4 & 8 & 25 & 33 & 50 & 50 & 50 & 26 & - & - \\
\hline $20-2$ 百 & 8 & 6 & 25 & 67 & 13 & 17 & 13 & 7 & - & - \\
\hline 2百一 -2 干 & 12 & 5 & 83 & 20 & 25 & 20 & 25 & 24 & 50 & - \\
\hline $2 千-5 千$ & 10 & 6 & 90 & 67 & 60 & 67 & 60 & 46 & 40 & 17 \\
\hline $5 \mp-1 万$ & 11 & 8 & 64 & 88 & 45 & 50 & 18 & 38 & 27 & 25 \\
\hline 1万以上 & 5 & 2 & 80 & 100 & 60 & - & 20 & 43 & 20 & - \\
\hline 合計 & 50 & 35 & 66 & 60 & 40 & 40 & 30 & 31 & 28 & 9 \\
\hline
\end{tabular}

表中の「垂直」は垂直衝撃、「機関」は機関異常を示す。各棇卜 ン数別および合計の行動瞥の数字は、それそれ各トン数別船船隻 数および合計船舶隻数に対する比率（\%) を示す。回答は複数回 答を含む。 
直衝撃」と「機関異常」別に、感じ方によ ってその後の船舶の行動にどのように影響 するのかを調查した。表 4 は総卜ン数別の 二つの海震の感じ方毎の船舶の行動を示す。 高い比率で「点検」を実施したのは「垂直 衝撃」を感じた 2 百トン以上の船舶であっ たが、「機関異常」を感じた船舶ではより大 型の 2 千トン以上の船舶であった。「機関操 作」は感じ方で大きな差はでなかったが、「予 定変更」及び「通報連絡」では「垂直衝撃」 を感じた船舶の方が $5 〜 6$ 割と高い比率を 示す場合が認められる。

\section{4 船舶の状態別の海震の感じ方と地震 後の船舶の行動}

表 5 に船舶の航行や操業中などの状態別 の海震の感じ方と地震後の船舶の行動を示 す。航行中の船舶は約 8 割、6 割と高い比 率で「垂直衝撃」と「機関異常」を感じ約 8 割の比率で「点検」を、操業中の漁船は 高い比率で「機関異常」を感じ「機関操作」 や「予定変更」を、錨泊中の船も高い比率 で「垂直衝撃」を感じ「点検」をそれぞれ 行った。しかし、係留船舶は全体的に低い 比率を示し、海震の感じ方も他の状態の船 舶とは異なっていた。

表 6 亿船舶の状態別の「垂直衝撃」と「機 関異常」を感じた船舶毎の行動を示す。両 方の感じ方に対して、航行中の船舶は約 6 〜 9 割と高い比率で「点検」と「機関操作」 を、操業中の漁船約 $5 \sim 10$ 割と高い比率で 「機関操作」を行った。又、「機関異常」を 感じた操業漁船は高い比率で「予定変更」を、「垂直衝撃」 を感じた錨泊船舶も高い比率で「点検」を行った。その他 の場合には明らかな傾向は認められなかった。当然のこと ではあるが、航行中の船舶や操業中の漁船は高い比率で自 船の安全確認及び航行のため「点検」や「機関操作」を行 ったことが判ったが、海震の感じ方による明らかな傾向は 認められなかった。

\section{5 地震情報入手}

地震情報入手に関しては合計106隻から157回答が得られ た。その結果を表 7 に示す。情報入手時期は「直後」と「数 分以内」とで約 7 割にも及ぶ。しかし、大きな衝撃を受け たにも拘わらず情報入手を行わず、1〜2時間後に地震発 答を含む。 を含む。
表 5 船舶の状態別の海震の感じ方と地震後の船舶の行動

\begin{tabular}{|c|c|c|c|c|c|c|c|c|c|}
\hline \multirow{3}{*}{ 船舶状良 } & \multirow{3}{*}{ 隻数 } & \multicolumn{4}{|c|}{ 海震の感じ方（\%） } & \multicolumn{4}{|c|}{ 船舶の行動（\%） } \\
\hline & & 垂直 & 水平 & 異常 & 機関 & 点侩 & 機関 & 予定 & 通報 \\
\hline & & 衝擊 & & & 異常 & & & & \\
\hline 航行中 & 36 & 75 & 14 & 17 & 56 & 78 & 61 & 31 & 25 \\
\hline 操業中 & 8 & 13 & - & - & 75 & 38 & 50 & 63 & - \\
\hline 鎮泊中 & 10 & 60 & 20 & 30 & - & 60 & - & 10 & 20 \\
\hline 係船中 & 48 & 33 & 23 & 16 & 19 & 40 & 2 & 35 & 8 \\
\hline 不 明 & 4 & - & - & - & - & - & - & - & - \\
\hline 合計 & 106 & 47 & 17 & 15 & 33 & 53 & 25 & 32 & 14 \\
\hline
\end{tabular}

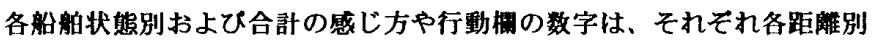
船舶隻数および合計船舶隻数に対する比率（\%）を示す。回答は複数回

表 6 船舶の状態別の垂直衝撃と機関異常を感じた船舶の行動

\begin{tabular}{|c|c|c|c|c|c|c|c|c|c|c|}
\hline \multirow{2}{*}{ 船舶状㮩 } & \multicolumn{2}{|c|}{ 隻数 } & \multicolumn{2}{|c|}{ 点 検 } & \multicolumn{2}{|c|}{ 機関操作 } & \multicolumn{2}{|c|}{ 予定変更 } & \multicolumn{2}{|c|}{ 通報連絡 } \\
\hline & 堹 & 裸 & 重直 & 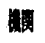 & 堹 & 裸 & 租 & 䀅 & 埴 & 畔 \\
\hline 航行中 & 27 & 20 & 81 & 85 & 70 & 55 & 37 & 20 & 30 & 15 \\
\hline 操手中 & 1 & 6 & - & 33 & 100 & 50 & - & 67 & - & - \\
\hline 錨泊中 & 6 & 0 & 67 & - & - & - & - & - & 33 & - \\
\hline 係船中 & 16 & 9 & 44 & 22 & - & - & 31 & 33 & 25 & - \\
\hline 合計 & 50 & 35 & 66 & 60 & 40 & 40 & 30 & 31 & 28 & 9 \\
\hline
\end{tabular}

表中の「垂直」は垂直得摮、「機関」は機関異常を示す。各船船 状態別およぴ合計の行動欄の数字は、それそれ各トン数別船舶数 および合計喤舶隻数に対する比率（\%）を示す。回答は複数回答

表 7 地震情報の入手時期と手段

\begin{tabular}{lclc}
\hline 入手時期 & 回答数 (\%) & 入手手段 & 回答数 (\%) \\
\cline { 1 - 1 } 直後 & 53 & テレビ & 36 \\
数分以内 & 16 & ラジオ & 8 \\
1 時間以内 & 5 & 業務無線 & 7 \\
2 時間以内 & 1 & VTS等 & 5 \\
その他 & 11 & 電話 & 1 \\
不明 & 13 & その他 & 29 \\
& & 不明 & 13 \\
\hline 対象般船数 & \multirow{2}{*}{106 隻 } & 全回答数 & 157回答 \\
\hline
\end{tabular}

回答数椚の数字は全回答数に対する比率（\%）を示 す。

生を知ったといらのも合計 $6 \%$ \%る。入手手段は船舶が沿岸域を航行していたこともあり、テレビが最も 多く、続いてラジオ、業務無線、VTS (Vessel Traffic Service、マーチスやポートラジオ) 等であった。 VTS施設が地震による被害を受けたこともあり又、陸上通信網の混乱によって情報収集と提供が的確に行 われなかったことから低い数字を示した。多くの回答が当時の通信網の大きな混乱と情報源からの隔絶を 
記載している。震災によ る被害状況を海上船舶に 伝える広域的な報道発信 がなされたのは、地震発 生時から何と12時間後の 午後 5 時 45 分であった。 現在、その時の状沉を基 に緊急時の通報網の改善 が行われている。

3.6 大阪湾周辺海域の 漁況変化

兵庫県 $\cdot$ 大阪府下の 27 漁業協同組合に地震発生 時及び直後の漁況・海象 変化の訪問調查を実施し た。それら漁沉変化を図 2 に示す。地震発生後、 大阪湾北部でカレイやシ ヤコエビ等の「底もの」、 明石海峡付近でタイ、神 戸沖のアジやサバ、尼崎

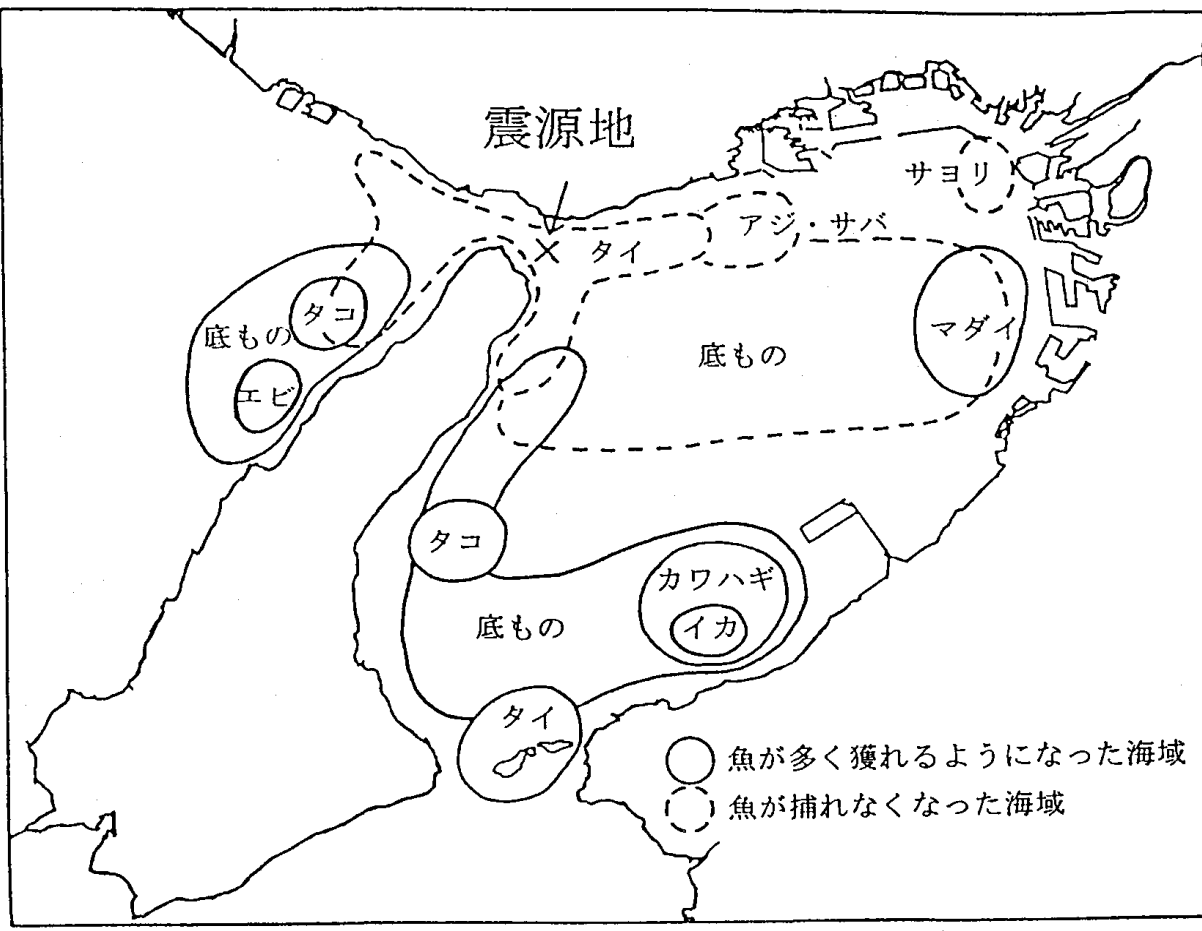

図 2 大阪湾周辺海域の漁況変化

図中、奉線で示したものは多く獲れるように変化した海域、破線は獲れなくなった海域を示す。 沖のサヨリなどの漁獲が

ほとんどなくなったり大きく減少した。一方、大阪湾南部から淡路島東岸にかけて「底もの」、泉南沖のイ カやカワハギ、友ヶ島水道のタイ、淡路島東岸中央部のタコ、西岸北部のタコ、エビ、底ものの漁獲がお 掠きく增大した。このような漁況の変化は地震による強い衝撃と海底質の大きな变化と関係があると考元 られる。大阪湾北部の海底では底質が地震発生後、よりやわらかな泥に変化し漁網が泥に深く食込み、多 くの泥が漁網に付着してくるとの報告が多かった。直後の漁況調查 ${ }^{(11)}$ と同様に、半年以上も後に実施した 本訪問調查の実施時期にもまだその変化が認められた。

\section{4. おわりに}

兵庫県南部地震の際、大阪湾周辺海域において航行、操業していた多くの船舶及び漁業関係者の異常体 験についてアンケート調查を行い、その異常体験の実態と船舶が遭遇した状況と安全対策や処理に関する 行動などについて検討を加えた。

多くの船舶で乗揚げたような強い垂直衝撃や、主機の爆発のような機関異常を感じた。そして多くの船 舶において自船の安全確認や航行のための対策や処理、行動が取られ、船体や機関の点検や機関減速や停 止等の機関操作が多く実施された。しかし一方、強い衝撃を受けたにも拘わらず何ら行動が実施されなか った場合も認められた。大型船舶の方が小型船舶に比べ、距離に関係なく強い衝撃を受けたと報告してお り又、高い比率で安全確認のための点検を行っている。異常の感じ方による船舶の行動の差はあまり認め られなかった。

大半の船舶は地震情報は地震直後、数分以内に入手した。入手手段の多くはテレビであった。地震発生 当時、公的通信網は大きな混乱をきたし、海上における船船は地震の情報入手に大きな困難をきたした。

最後に、本アンケート調查を行らにあたり、多大なるご協力を頂いた調査対象関係諸機関・団体、及び 調查実施担当・関係各位にここに深く感謝致します。なお、本調查研究は文部省特別研究、神戸商船大学 震災研究会「兵庫県南部地震による港湾・物流分野の損害と復興対策に関寸る研究」の一環としてなされ たものである。 


\section{参 考 文 献}

（1）気象庁：災害時地震 - 津波時報，平成 7 年度（1995年）兵庫県南部地震，p.p.21，1995年 1 月.

(2) 土木学会：阪神大震災震害調査緊急報告会資料, p.p.92,1995年 1 月.

（3）土木学会：土木学会阪神大震災震害調査第 2 次報告会資料，p.p.168，1995年 3 月.

(4) 神戸商船大学震災研究会：神戸商船大学震災研究会研究報告，第 1 号，p.p.405，1996年 1 月.

（5）石田廣史：兵庫県南部地震による神戸港被災状況，日本航海学会誌NAVIGATION，第125号，5-11， 1995年 9 月.

（6） 社団法人神戸海難防止研究会：会報 2 号阪神・淡路大震災特集号，210-225，1996年 1 月.

(7) 社団法人日本パイロット協会：水先区だよりパイロット，No.90，114-129，1995年 5 月.

(8) 石田廣史・千頭 亨：兵庫県南部地震の際の海上及び海岸付近における異常体験に関するアンケート 調查, 神戸商船大学震災研究会報告, 第 1 号, 83-109, 1996年 1 月.

(9) 石田廣史, 千頭 亨：兵庫県南部地震の際の船舶乗組員の異常体験に関するアンケート調查の解析一 例，日本航海学会誌，NAVIGATION，第128号，1996年 6 月.

(10) 石田廣史・千頭 亨：兵庫県南部地震の際の船舶及び漁業関係者の異常体験に関するアンケート調查 集計概要, 神戸商船大学震災研究会報告, 第 2 号, 1996年12月（印刷中）。

(11) 鍋島靖信 : 兵庫県南部地震における大阪湾の水産生物と漁業への影響, 水産海洋学会水産海洋研究, 第59号第 3 卷，293-305，1995年 7 月.

\section{質 疑 応 答}

濱田悦之（東京水産大学）：(1) 縦摇れ、横摇れとは何ですか。

(2) 海底が泥に变わったとのことだが、以前は何だったのか。

千頭 亨：ご質問有難うございます。ご質問の(1) 縦摇れとは、アンケート調査の回答では乗揚げたよう な垂直方向の衝撃を又、横摇れとは水平方向の衝撃を表します。ローリング、ピッチングとの混同を避 けるため垂直衝撃、水平衝撃と表します。(2) 底質については漁業関係者からの回答では、以前と比べ ると網が海底の泥に樑く潜り込んだり、網に多くの泥が付くことから、砂もしくは固い泥底質が拳かい 泥底質に変わったと考光られます。

菊地 剛（日本船長協会）：異常時、地震と感じたという回答は何件あったか。

千頭 亨：ご質問有難うございます。対象船舶106隻の157回答中、地震直後に地震と知ったというのは83 件で、数分以内にラジオ等で情報を入手し地震と知った場合を加えると108件です。 